\title{
化学物質分野における安全目標 一静的アプローチから動的アプローチへ
}

岸本充生

\section{1. はじめに}

工業化学物質や食品中化学物質といった分野 では、二種類のリスク管理アプローチが用いら れている。一つは、これ以下なら影響が見られ ないとされる間值を設定しないケースである。 その場合は、実質的に安全であるとみなされる リスクレベルをあらかじめ決めたうえで、安全 目標を定めるアプローチがとられている。もう 一つは闇值の存在が想定されるケースである。 こうした場合はこれまで、閾值をもとに算出さ れた基準值があたかもリスクがゼロであるか のような対応がなされてきた。本稿では、この ような現状のリスク管理アプローチを概観し たうえで、これらの「静的な」アプローチに代 わる、「動的な」アプローチとして運用されう る三つのリスク管理の考え方、すなわち MOE、 BAT、ALARAを紹介し、こうした動的アプロー チが機能するための条件を提示する。

\section{2. 現行の規制アプローチ}

\section{（1）化学物質を二種類に区分}

化学物質は規制上、図1のように、遺伝毒性 を持つ発がん性物質であるか (右側)、それ以 外か（左側）によって、リスク管理の方法が異 なる（岸本 2012）。

遺伝毒性とは、発がんの作用メカニズムが 遺伝子を直接傷付ける形をとると想定されるも

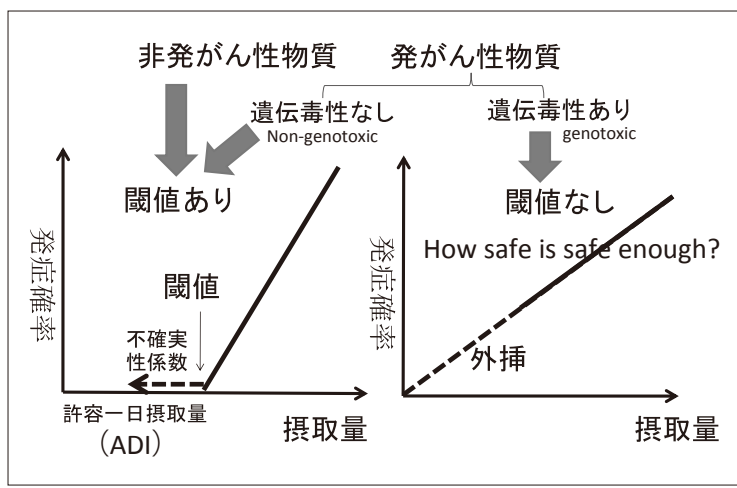

図 1 化学物質の閾值あり（左）と閾値なし（右）

のを指す。放射性物質は遺伝毒性を持つため、 図1の右側に該当する。これが線形閾值無し （LNT）仮説である。

（2）閾値が存在すると仮定するケース

閾值が存在するとみなされる場合は、動物 試験やヒト疫学調査において影響が観察されな かった濃度を無毒性量（NOAEL）と呼び、こ れを不確実性係数で割ることによって一日許容 摂取量 (ADI) が導出される。動物試験データ を利用する場合の不確実性係数は基本的には、 動物からヒトへの種間外挿で10、ヒトの中での 個人差で10、合わせて100が用いられる。曝露 量がADIを下回るとリスクがゼロであるかの ような説明がなされることも多いが、あくまで もラット等の動物について 50 匹程度で悪影響 が観察されなかっただけであり、必ずしもリス クがゼロであることを示しているのではないこ とに注意すべきである。

（3）閾値が存在しないと仮定するケース

1980年代頃までは、大気においても水道水 
においても、発がん性物質は検出されないもの とされてきた。ところが、複数の微量の発がん 性物質が大気中や水道水中に含まれることが明 らかになってきたため、1990年代になり、水道 水では世界保健機関（WHO）に従い、遺伝毒 性発がん性物質の基準值（図1の右側）は生涯 発がんリスクレベル $10^{-5}$ (10万人に 1 人ががん で死亡する）を安全目標として設定することに なった。ただし、このときは、日本人にはリス クに基づく議論は時期尚早であるとしてリスク レベルは明示されなかった。その後、大気につ いて同様の諮問を受けた中央環境審議会が1996 年、中間答申において、「・・・閾值がない物 質については、曝露量から予測される健康リス クが十分低い場合には実質的には安全とみなす ことができるという考え方に基づいてリスクレ ベルを設定し、そのレベルに相当する環境目標 值を定めることが適切である」とし、続く第二 次答申において「現段階においては、生涯リス クレベル $10^{-5}$ を当面の目標に、有害大気污染物 質対策に着手していくことが適当である」とし た。同時に、生涯発がんリスクレベル $10^{-5}$ に基 づき、ベンゼンの環境基準值が $3 \mu \mathrm{g} / \mathrm{m}^{3}$ に設定 された。

\section{（4）食品安全分野}

食品中の化学物質では添加物などの意図的な ものについては、発がん性物質は原則禁止され ている。例えば、動物試験で発がん性が判明し、 またその成分に遺伝毒性の疑いが生じたアカネ

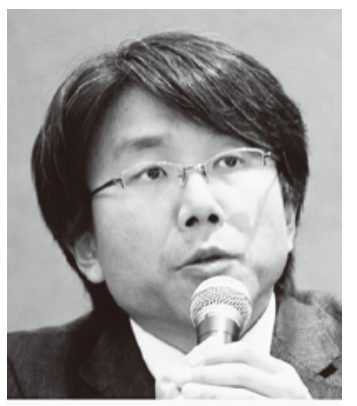

\section{PROFILE}

岸本充生

(きしもと あつお)

東京大学公共政策大学院・政策ビジ

ヨン研究センター 特任教授

専門:リスク学、経済分析
色素は使用がただちに禁止された。しかし、意 図しない副生成物や污染物質の場合は含有量を ゼロにすることは困難であり、またコメを始め、 多くの主要な食品が該当するため、摂取自体を 禁止にすることもできない。そのため、近年、 第4節で紹介するように、別の対応が模索され ている。

\section{（5）放射線分野}

放射線への被曝によるヒト健康影響は、確定 的影響と確率的影響に分けられる（図2）。

$\mathrm{X}$ 線や放射能が発見され、医学に応用される ようになると、最初に皮膚障害をはじめとする 急性の放射線障害が報告されるようになった。 このような放射線障害には、これ以下なら障害 が生じない線量レベル、すなわち間值があるこ とが分かり、これは確定的影響と呼ばれる。

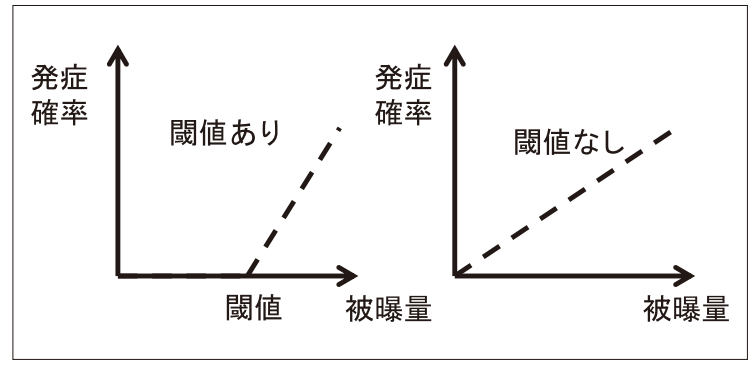

図2 放射線の確定的影響（左）と確率的影響（右） 
しかし、医療行為において放射線を受けた患者 の中から統計的に有意に白血病が誘発されるこ と、さらに、広島・長崎の原爆被爆生存者の疫 学調査においても白血病の発症頻度の増加が観 察されるようになったこと、などが報告され始 めると、急性影響である確定的影響に加えて、 潜伏期間をもって発症する慢性的影響の存在が 明らかになってきた。後者においては、これ以 下なら影響が現れないという間值を明示するこ とが困難であったため、国際放射線防護委員会 （ICRP）は、リスク概念を使って、がんの発症 頻度には閾值がなく、蓄積線量に比例するとす る安全側の仮定（LNT仮説）を導入した。し かし、放射線被曝に関しては、遺伝毒性発がん 化学物質のような安全目標が設定されなかった ため、福島第一原子力発電所における事故のの ち、食品等から検出される放射性セシウムの安 全性を巡って多様な見解が噴出することになっ た（川口・岸本 2012）。

\section{3. 安全目標アプローチの効能と 限界}

安全目標アプローチは一見クリアで、安全と 危険をはっきり区別できる（ように見える）た め、リスクコミュニケーション上も便利である と考えられる場合が多い。しかし、安全目標レ ベルの根拠を科学的に説明することは不可能で あり、たまたまこの程度なら達成可能であると 考えられて設定されたものである。化学物質分
野において、遺伝毒性を持つ発がん性物質につ

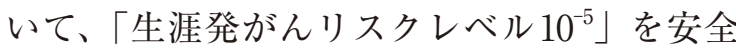
目標として決めた1990年代はパブリックコメ ント制度が導入される前であり、一般にはほと んど知られることなく、専門家の間の議論で決 まった「落としどころ」であった。中央環境審 議会の答申には「現段階においては」「当面の 目標に」と書かれ、近い将来、見直される含み が持たされていたが、一度定められたものを変 更することは非常に難しく、実際、20年近く経っ ても見直される気配は全くない。安全目標アプ ローチは、常に見直され改訂されていくことも 理論的には可能であるものの、実際には静的な 性格が強くならざるをえない。

また、すべての物質に同一水準の安全目標を 適用すべきであるという正当な理由はない。実 際、米国環境保護庁は $10^{-6}$ を安全目標としてい る。原発事故後に放射性セシウムの污染が生じ た際には、この「生涯摂取し続けて 10 万人に 1 人が発がんで死亡するレベル」を適用しては どうかという提案もあったが、これを適用する と、放射性セシウムの基準值が生涯累積被曝限 度 $0.2 \mathrm{mSv}$ 程度という非現実的な值となってし まう。また、放射線では自然起源分は所与とし て除外して人為分のみについてリスク管理を行 うが、化学物質では自然起源分も含めた数字を もとにリスク管理を行う。

こうしたことから、一律の目標レベルを恣意 的に設定するよりも、できるだけ曝露を減らし ていくという現実的なアプローチも次節で紹介 
するように様々な文献で提案されている。

\section{4. 代替的なアプローチ}

ここでは、安全目標に代表される静的なアプ ローチに対して、実際に採用されており、動的 なアプローチになりうる三つの考え方を概観す る。

\section{（1） MOEアプローチ}

食品安全の分野では、遺伝毒性を持つ発が ん性物質のリスク評価において、従来は意図的 な物質については添加や摂取を一切認めないと いうアプローチがとられてきた。非意図的な物 質については、清涼飲料水中に副生するベンゼ ンのように、大気や水道水と同様、 $10^{-5}$ レベル を安全目標とするアプローチが採用されている 例もあるものの、食品そのものについては、曝 露マージン（Margin of Exposure：MOE）を 使ったリスク管理に移行しつつある。MOEア プローチは、曝露量の予測值あるいは計測值を、 用量反応データから統計的に導出されたベン チマーク用量の信頼下限值（BMDL）で割った 值と定義されている。BMDLはPoD（Point of Departure）と呼ばれ、通常、動物試験におい て統計的に $10 \%$ の追加的な影響を引き起こす レベルの 95\%信頼下限值である。

$\mathrm{MOE}$ 概念は 2005 年にFAO と WHO の共同専 門家委員会（JECFA）で採用されたのが始ま りである（FAO/WHO 2005）。日本でも食品安 全委員会において、遺伝毒性を持つ発がん性物
質であるアクリルアミドなどのリスク評価にお いて採用されている。アクリルアミドは、2002 年にスウェーデン政府の発表により、炭水化物 の多い食品を揚げたり焼いたりした場合に生成 し、数多くの食品に比較的高濃度に含まれてい ることが明らかとなった物質である。

MOEアプローチの利点としては、数字の小 さいものほどリスクが高いことを示しており、 リスク管理において優先順位付けに便利である ことが挙げられる。通常の目安は、MOEが 1万を超えるとリスクの懸念が小さいと評価さ れるが、それよりも小さい場合はリスク削減の 努力を行うことが望ましいとされる。ただし、 相対的な評価自体は従来型の発がんリスクレベ ルでも可能である。MOEアプローチが導入さ れた背景には、いくつかの遺伝毒性物質、例え ば無機ヒ素やアクリルアミドなどをリスクレベ ルで管理しょうとすると、通常私たちが摂取し ている食品に抏いて、大気や水道水で採用され ている安全目標である $10^{-5}$ をきく超えてしま う「矛盾」が露わになってしまうという事情も あったのだと考えられる。

\section{(2) BATアプローチ}

化学物質の審査及び製造等の規制に関する法 律 (化審法) では、第一種特定化学物質に指定 されると、その物質の製造、輸入及び使用が原 則禁止される。しかし、製造や加工のプロセス において非意図的に副生してしまう場合はゼロ にすることが困難である。そのため、2007年に は「第一種特定化学物質に該当する化学物質が 
他の化学物質に副生成物として微量含まれる場 合であって、当該副生成物による環境の污染を 通じた人の健康を損なうおそれ又は動植物の生 息若しくは生育に支障を及ぼすおそれがなく、 その含有割合が工業技術的・経済的に可能なレ ベルまで低減していると認められるときは、当 該副生成物は第一種特定化学物質としては取り 扱わないものとする」とされた。さらに翌年、 これが「利用可能な最良の技術 (BAT : Best Available Technology/ Techniques)」と名付 けられ、「工業技術的・経済的に可能なレベル」 まで低減すべきとの考え方が採用された（厚生 労働省ら 2008)。このルールに従い、顔料又は 染料の原料となるテトラクロロ無水フタル酸の 中に副生していることが判明したへキサクロロ ベンゼン（HCB）について、製造及び輸入事業 者からの技術的可能性と対策費用に関する詳細 な聞き取り調査に基づいて、限界費用曲線を導 出したうえで、技術的・経済的に可能なレベル として200ppmが定められた（副生する特定化 学物質のBAT削減レベルに関する評価委員会 2006)。

BATという考え方は1996年に制定された欧 州の統合污染防止管理（IPCC）指令の中で初 めて定義された。その後、国際条約などでも採 用されるようになった。2013年に採択された「水 銀に関する水俣条約」においても、石炭火力発 電所などの排出源からの大気排出対策として、 新設施設へのBATの適用が義務付けられてい る。しかし、BATアプローチは、BAT技術リ
ストを指定する形で運用される例が多く、見直 されなければ、動的に運用されないばかりか、 かえって技術革新を阻害することにもなりかね ない。

(3) ALARA アプローチ

ALARAとは「合理的に達成可能な限り できるだけ低く（As Low As Reasonably Achievable)」を意味する言葉で、放射線防護 の分野において、ICRPの1977年勧告において 正式に提示された。被曝を社会的・経済的要因 を考慮に入れながら合理的に達成可能な限り低 く抑えるべきであるという原則であり、LNT 仮説のもとでリスクとコストのバランスを取る ことが含意されている。「最適化」の概念と同 義である。類似の概念に、労働安全衛生分野 で用いられるALARP（As Low As Reasonably Practicable）原則がある。

ALARA原則は食品の分野においても、コー デックス委員会の食品污染物質部会 $(\mathrm{CCCF})$ において、食品中の污染物質の最大基準值設定 の際に用いられている。例えば、カビ毒である アフラトキシンなどに適用されている。農林水 産省では「無理なく到達可能な範囲でできるだ け低くすべき」と和訳されている。しかし、食 品分野はもちろん、放射線分野においてさえ ALARAを運用するための具体的な手順は定め られていない。 


\section{5. 動的アプローチを 活用するには}

前節で紹介した動的なアプローチも欠点を 持つ。一つは恣意的な運用が可能である点であ る。MOEアプローチでは相対的な比較ができ ても、どこまで対策をすれば十分であるのか （1万を超えればリスクの懸念なしとされる以 外は）自明ではない。BATアプローチも実際、 何をもって、技術的・経済的に実施可能である か判定することは非常に難しい。ALARAアプ ローチも、現状の正当化に用いられる恐れがあ る。

これらの潜在的な動的アプローチを、真の 意味で動的に運用するには、それぞれをエビデ ンスに基づくアプローチとし、定期的な見直し とセットで導入することが必要不可欠である。 そのために必要な作業は、複数のオプション とそれらを達成するための費用と、達成するこ とで得られるリスク削減量をできるだけ定量的 に示すことである。これは、まさに規制影響 評価（RIA）の考え方であり、OECDがたびた び加盟国にRIAの活用を勧告しており（OECD 2012)、日本に打いても2007年から法律と政令 を対象に制度化され、毎年100件近くの評価書 が公表されている（岸本 2013）。しかし、RIA は残念ながら、日本では意図した機能を果たせ ていない。費用や効果の定量化が少なく、実施 のタイミングも遅すぎるために、法規制の策定 プロセスの改善に役に立っていない。第4節で
概観した三つの潜在的に動的なアプローチを、 現状を正当化するための道具ではなく、文字通 りに可能な限りリスクを小さくし続けるための 意思決定ツールとして実体を伴ったものにする には、RIAアプローチとセットで導入されるべ きである。そのためには、運用ガイドラインの 整備と、常にエビデンスを求める社会からの監 視の目が必要不可欠である。

\section{参考文献}

副生する特定化学物質のB A T 削減レベルに関する評価委員 会 (2006) . TCPA及びソルベントレッド135中の副生 HCBに係る BATレベルに関する報告書.

FAO/WHO (2005). Joint FAO/WHO Expert Committee on Food Additives (JECFA). Summary and Conclusions: 64th meeting, Rome, 8-17 February 2005.

川口勇生、岸本充生 (2012). 放射線リスク再考一科学は今ど こまで語れるか. 化学67(11)1:54-56.

岸本充生 (2012) . 安全性確保と社会受容のためのリスク評価 の方法と課題. 都市清掃65(308): 331-336.

岸本充生（2013）。透明で合理的な意思決定と環境／健康影響 の解明、定量化をつなぐ規制影響評価. 環境情報科学414: 42-47.

厚生労働省、経済産業省、環境省（2008）。副生第一種特定化 学物質を含有する化学物質の取扱いについて（お知らせ）. 平成20年12月26日.

OECD (2012). Recommendation of the Council on Regulatory Policy and Governance. The OECD Regulatory Policy Committee. 